Journal of

Neurophysiology and Neurological Disorders

\title{
Migraine and osmophobia: What can we do?
}

\section{Raimundo Pereira Silva-Néto}

Federal University of Piauí, Teresina, Brazil

${ }^{*}$ Corresponding author: R. P. Silva-Néto, Health Sciences Center, Federal University of Piauí, Avenida Frei Serafim, 2280, Centro, Teresina, PI64001-020, Brazil, Tel: + 55 863215-5696; E-mail: neurocefaleia@terra.com.br

Received Date: April 16, 2019 Accepted Date: April 30, 2019 Published Date: May 04, 2019

Citation: Raimundo Pereira Silva-Néto (2019) Migraine and osmophobia: What can we do? J Neurophysiol Neurol Disord 5: 1-2.

\section{Dear Editor,}

I have read with great interest the article written by Park et al. entitled "Osmophobia and allodynia are critical factors for suicidality in patients with migraine", in which the authors concluded that osmophobia is a critical factor for suicidality in migraine patients [1]. This finding has a significant social impact on the lives of migraine patients.

Osmophobia is defined as intolerance to odors and it is associated to primary headaches, particularly to migraine with or without aura during headache attacks. However, it may be present in the absence of pain (period between attacks) only in migraine patients [2].

The exact mechanism of osmophobia is unknown. However, a study by fMRI during headache attacks in migraine patients and normal subjects showed increased activity of the limbic system and brainstem in response to olfactory stimulation, and only in migraine patients. These

C2019 The Authors. Published by the JScholar under the terms of the Creative Commons Attribution License http://creativecommons.org/licenses/ by/3.0/, which permits unrestricted use, provided the original author and source are credited. findings have demonstrated that olfactory processing is altered during headache attacks in migraine patients, suggesting that there are specific neuronal connections between the olfactory and trigeminal nociceptive systems [3].

Osmophobia interferes in the quality of life of migraine patients, as some patients are daily exposed to odors in their professional activities. In addition, osmophobia is a critical factor for suicidality in migraine patients [1]. For those reasons, it becomes necessary to treat osmophobia.

Several categories of drugs are used in migraine prophylaxis, such as beta-adrenergic blockers, tricyclic antidepressants, calcium channel blockers, serotonergic antagonist, antiepileptics, and others. All of these drugs are effective in controlling pain, but with no influence in osmophobia.

Cognitive-behavioral therapy is a suggestion of non-drug therapy for osmophobia. It is based in the exposure of the patient to odor and thus helps educate him/her about his/her odor intolerance. Hypnotherapy and relaxation techniques are other alternative therapies in the control of osmophobia 
A specific drug has been sought to treat osmophobia in recent years. Since 1986, phenytoin, an antiepileptic drug not used in migraine prophylaxis, has been suggested to treat the central and autonomic disturbances of migraine, such as osmophobia, hyperosmia, pain in the limbs and motion sickness that occur in the pain-free period [4].

We recently published a case report in which the patient complained of severe osmophobia. Migraine prophylaxis provided a marked improvement in the frequency and intensity of headache attacksof this patient, but osmophobia remained unchanged. A prophylactic treatment with phenytoin was started, at a dose of $100 \mathrm{mg}$ once a day. After 90 days, the patient became asymptomatic and remained without osmophobia for the following two years [5].

In conclusion, I believe that further studies should be carried out on osmophobia and that this symptom could be controlled in the near future.

\section{Compliance with ethical standards}

Conflict of interest: The author declared no potential conflicts of interest with respect to the research, authorship, and/or publication of this article.

\section{References}

1. Park SP, Seo JG, Lee WK (2015) Osmophobia and allodynia are critical factors for suicidality in patients with migraine. J Headache Pain 16:529.

2. Silva-Néto RP, Peres MF, Valença MM (2014) Accuracy of osmophobia in the differential diagnosis between migraine and tension-type headache. J Neurol Sci 339:118-122.

3. Stankewitz A, May A (2011) Increased limbic and brainstem activity during migraine attacks following olfactory stimulation. Neurology 77:476482.

4. Raffaelli Júnior E, Martins OJ, Dágua Filho AS (1986) A role for anticonvulsants in migraine. Funct Neurol 1:495-498.

5. Silva-Néto RP (2016) Phenytoin in the treatment of osmophobia in migraine patient: A case report. J Clin Case Rep 6:749.
Submit your manuscript to a JScholar journal and benefit from:

ฯ Convenient online submission

ब Rigorous peer review

I Immediate publication on acceptance

ๆ Open access: articles freely available online

ब High visibility within the field

- Better discount for your subsequent articles

Submit your manuscript at http://www.jscholaronline.org/submit-manuscript.php 